\title{
Folk Tales As A Character Education Tool For Children
}

\author{
Supardjo $^{1}$, Dyah Padmaningsih ${ }^{2}$, Sujono $^{3}$ \\ Universitas Sebelas Maret
}

\begin{abstract}
Folk tales are an effective fictional stories to convey moral messages and a means of character education, especially for children. The content of the story is a folklore and a true story by using objects as symbols, animals or plants that are conveyed orally so as to form a story of a life journey and contains moral messages on how to interact with other beings. The article "Fairytale as a Means of Character Education for Children" is part of an active independent research entitled "The Value of Character in Javanese Language Tales with the basis of Child Character Education (Ethnolinguistics)". This study aimed to describe the character learning through tales. This research was conducted through qualitative descriptive research. Data sources are in the form or oral data that came from informants. The data used in this study are tales in Javanese. The collection of data used interview technique with informants. e the problem using the matching method. Based on the results of data analysis, folk tales illustrate such characteristics as follows: sincere, honest, accepting, harmonious, and patient.
\end{abstract}

Keywords : Tale, Learning, Character, Children

\section{Introduction}

Folk tales or folklore included in the literary prose literature or folklore, because it was first passed orally, or through the word of mouth. From the content of the tales, it is usually a fictional folklore and a true story using the symbol of objects, animals or plants, the occurrence of a place, the heroism of a character, expertise or mastery of high science, that are conveyed orally so as to form a story of a life journey and contains moral messages on how to interact with other beings.

Folk tales are the easiest and most communicative character learning tool for children, because in general the majority of children enjoy listening to folk tales, like animal tales about animals that tell stories about help, play strategies, folk tales will be more communicative and can be well understood by the listeners, especially children - if tales are delivered orally using simple language, because they do not have rules such as the macapat song, and do not tell specific space and time, and the story line is easy to follow. In its development many folk tales experience changes, such as development of story line, the choice of words depends on the mastery of the language of the storyteller and who the listeners are, as well as the media used, 
because the tales are spoken orally and the abilities of people and regions differ, but the content or message remains the same.

Therefore, the tradition of storytelling needs to be grown again, either through competitions / festivals, storytelling in class by teachers, storytelling when lulling their children by parents. The importance of storytelling today is that it can be used as a means of character education tool and manners education tool, because the message contained in fairy tales in the form of moral teachings, advice and can be used as emotional control of children.

Storytelling requires language that is easily understood with interesting presentations, such as the different voice for different characters, a clear emphasis in tones so that it will reflect the meaning that is educating and entertaining. Tales are loaded with moral messages for those who hear them, such as entertainment, religious values, harmony, sarcasms and others.

Folk Tales are a prose literary works that are believed by a society to be true, although many folk tales illustrate fictional events in fiction that are not considered to have really occurred, only as a form of entertainment. The contents of folk tales mostly describe a truth, example, moral lessons, and some are even the form of satire[1].

Folktales are a form of folklores because they are conveyed orally through the word of mouth, anytime depends on the storyteller condition. Folk tales are also a form of folklores because folklore is also a science that explains about culture in society such as gossip, tales, etc., and has value. Values are rules or instructions in identifying what is required, allowed, and prohibited. Value involves the matter of how to determine something is more valuable than others or if something should be accepted or rejected[2].

Values is closely related to education. Values relates to morals, attitudes, and behavior. Educational values are things that lead to the formation of morals, attitudes, and behaviors to make someone have spiritual, religious, self-control, personality, intelligence, and noble character. Education is a well-planned and systematic effort to realize a directed teaching and learning process so that students are more creative and innovative in order to develop their potential, such as religious understanding, tolerance, good morals, leadership, noble personality, intelligence, exemplary, that they will be beneficial for themselves and others.

Educational value is very closely related to literary works. Every good literary work always expresses noble values which are beneficial for its readers. The educational value referred involves moral education, religion, social, and aesthetic (beauty) values. This is in accordance with Waluyo's statement that states that the value of literature means goodness that exists in the meaning of literary works for life[3]. The educational value of literary works can be taken from meanings that can be enjoyed, understood, and applied by readers. Literature as a product of life contains social values, philosophy, religion, and so on both that originate from re-disclosure or those that have a new concept of proffering[4]. One of the literary works is in the form of folk tales or folklore. Values in folk tales depend heavily on perceptions and sensitivity possessed by readers or listeners. Therefore, in teaching and explaining the contents of fairy tales must be adjusted to the level of intelligence, age and natural experience of the child's imagination.

Character education can be interpreted as a process of instilling values to help students become smart and good in three aspects such as cognitive (head), affective (heart) and psychomotoric (hand). Character education is a system of instilling character values for school members which includes components such as knowledge, awareness or will, and actions to carry out these values both towards God Almighty, self, others, environment, and nationality so that they become perfect human beings[5].

Character education has the same essence and meaning as moral education and character education. The goal is to shape the child's personality so that they becomes a good human 
being for himself, for other people / society, so that the child can choose which is good and which is bad, and can understand that each choice comes with consequences. Therefore the shaping of character is very important for children, because their character, behavior, and personality will be shaped from an early age and the child will be able to develop the abilities they have.

There are various ways to realize the character education of children, one of which, introduces local culture such as traditional Javanese song / tembang which has noble values / adiluhung of valuable Javanese culture. The introduction of dolanan songs will be more quickly absorbed by children if done by parents or teachers, those who are the closest and most respected by children.

In Javanese folklore there are moral values that can be applied in everyday life, especially in shaping character of children. Characters in this study are morals, mental nature or character possessed by children to distinguish them from other children's behavior, character, and personality. According to Furqon, that the character is a mental or moral quality, moral strength, name or reputation, so that the character has to do with character which is interpreted as behavior, temperament, character and personality[6]. Operational character is a positive behavior carried out through habit. This means that someone is taught something good from childhood through intensive or repetitive exercises. Therefore forming the character of children can be done through folk tales that are cheerful and happy that the children will be happy to listen to them repeatedly.

\section{Research Method}

This research is a is descriptive qualitative research that is a research procedure that produces descriptive data in the form of words or writing. Qualitative research is a study aimed at describing and analyzing phenomena, events, social activities, attitudes, beliefs, perceptions, thoughts of individuals individually or in groups.

This study aims to describe, disclose, and explain and describe linguistic phenomena in accordance with facts in the community in the form of language sign systems, language symbols, and meanings using conquest, methods, research techniques, and the workings of cultural sociology research. This research seeks to dig information of the object of study by describing all that can provide deep interpretation.

Sources of data in the study are in the form of oral data derived from selected informants who met predetermined criterias. This research data in the form of words, phrases, sentences in Javanese used in folk tales in the Javanese language.

The method is a way of approaching, observing, and analyzing existing symptoms [7]. The data was collected through a listening method. Listening method, which is a method of collecting data by listening to the use of language. The implementation is followed up by using the note taking technique. The recording of relevant linguistic data is carried out with certain transcriptions according to their interests[8]. The first step in the method of referring to using note-taking techniques, the researcher is listening carefully, precisely, and thoroughly to the main data source in order to obtain the desired data in accordance with the research objectives. The second step, namely recording data that has been obtained from the source specified in the form of a data card. The next step is to classify and analyze language according to the problem so that it can achieve the goal. 
This research found the informants using purposive sampling techniques with snowball sampling models, namely the use of informants that multiply after research is carried out in the field[9]. The problem analysis used understanding, contextual and matching methods. The understanding method was used to understand the language used in folk tales to avoid misinterpretation, while in contextual, that in analysis other than the lingual unit used in folk tales, it also involves the underlying context where an event occurs in a folk tale in order to be able to describe what how it is / according to the context. The matching method is a method used to study or determine the identity of certain lingual units using determinants that are outside of language, regardless of language and are not part of the language related[8].

\section{Results And Discussion}

Tradition is something that has been done for a long time and becomes part of the life of a community group, usually from a country, culture, time or religion. The most basic thing of tradition is the information that is passed on from generation to generation both written and oral, because without this, the tradition will become extinct[10].

Ethics comes from Ancient Greek. The word ethos in a single form has many meanings: ordinary dwellings, pastures, cages, habits, customs, morals, feelings, attitudes, ways of estimating. Whereas in the plural (ta etha) meaning is custom. Aristotle used the notion of the plural form of the word ethos or ethics to show moral philosophy. Morals come from Latin, namely $\operatorname{mos}$ (plural $=$ mores) which means also: habits, customs. So etymologically the word ethics is the same as the estimation of moral words. Ethics can be interpreted as norms that become a guide to regulate the behavior of a person or group[11].

Myth is a story that provides certain guidelines and directions to a group of people. Myth is formed by ancient people, the existence of myth can increase a person to obey a rule. That myth gives direction to human behavior and is a kind of guideline for human wisdom[12] [13]. This research is a field research using purposive sampling technique and snawball sampling model. To answer the problem and the purpose of this research, we maximised the use of the informants, so that we could find the values of character in fairy tales as follows:

\section{a. Sincerity}

To be sincere means clean from dirt and makes something clean and not dirty. The nature of sincerity is an act that is done without strings attached, or acts based on purity to help others without asking for compensation in any form. Tales that contain character learning such as sincerity reflected in the stories of Kethek and Bulus. Both are friends, but Kethek always uses Bulus for his own benefit. On a trip in the forest, Kethek always sits on the back of Bulus, but when passing through a fruit tree, for some reason Kethek takes his own food. When Bulus asked why he did that, Kethek answered that the rotten fruit had been eaten by other animals but Bulus was not angry.

Do commendable actions with sincerity and full of hard work, God willing, will produce extraordinary good things. This is symbolized in the fairy tale character above, namely Bulus who has a sincere nature. And do not do and act of kindness only to expect the praise of others, as this does not mean any other than expecting something big without doing hard work. Such behavior will certainly only get undesirable bad things Tales like this need to be taught to children by taking or emphasizing the nature of sincerity of Bulus. 


\section{b. Honest}

Do not take something that is not ours, all life in the world has been arranged by the God the Almigthy, for sustenance, death, soul mate, has been arranged by the Creator.

The citation in folktale entitled hare stealing cucumber (Kancil Nyolong Timun) basically the hare steals cucumber in a garden when the farmer was not around, and several days later the farmer found out that the garden was damaged and the cucumbers began to run out and it made the farmer to think set up a trap to catch the garden destroyer animal.

The hare was captured and was brought home by the farmer to be cooked as food, but through his cunning nature, the hare could escape by tricking a dog. Therefore it must be realized and taught that we can not take what is not ours.

\section{c. Accepting}

A friendship that has been built for a long time could be hurt by greediness, and if it gets worse, the friendship that has been built could be broken.

This is symbolized in the fable of Monkey and Duck (Kethek dan Itik). Monkey has a greedy nature towards his best friend, namely Duck although Duck is very happy to be friends with monkey and trusts him, then one day that that trust is destroyed by the Monkey who wants to eat the ducks. The Duck has a strategy to go to the island across where the Monkey cannot swim. The long-awaited time has arrived, so one by one the Ducks began to cross the lake When crossing the Kethek was drowning because he could not swim. So that the Kethek did not eat Duck and then he realized that what he did was bad. Kethek is aware, what he did was harm to others, then accepting/ thankful for what he has (nrima ing pandum) needs to be his life principle.

\section{d. Harmonious}

Illustration of harmonious relationship can be seen from Ant and Wasp (Semut lan Tawon) tale. They always resolve problems together, without belittling one another. They live their life with a very strong sense of friendship. This tale needs to be socialized to children, because in this tale there is a good character education about harmony in friendships.

The tale begins with ant and wasp both foraging in the woods. It was the dry season, so that both of them had difficulty in finding food, in the middle of the trip they met and told stories. Finally it was decided theat they would both find food together. Arriving at the edge of the lake, the two stopped to drink and decided to reside in a tree on the edge of the lake and promised not to harm each other. Until now ant eggs are not eaten by wasps, and honey wasps are not eaten by ants. It was to honor the promise that they made.

\section{e. Patience}

The King's Empress was slandered by his mistress, saying that she wanted to kill the king by poisoning the king's food, upon hearing this the king got furious and he ordered the governor to abandon the empress in a forest. The empress then gave birth to a boy named Cindelaras.

Cindelaras has a best friend, a rooster, but the rooster is unlike any normal chicken, this rooster can talk. The rooster tells him the truth about his life, and on the other hand in the kingdom held a rooster battle contest, and the owner of he winning rooster will win a prize of a half of the kingdom. Upon hearing the news, Cindelaras decided to take a part in this contest. Long story short, Cindelaras' rooster fought with the King's rooster, resulted in the the King's rooster losing the fight. The Cindelaras' true identity was then revealed by the roosterm and everyone was in shock to learn that the rooster could talk, that he said that this boy is the son of the empress who was abandoned because she was slandered by the King's mistress. 
Upon learning the news, the King pleaded for forgiveness from his son and his mistress was given a heavy punishment. Upon hearing the news, pleaded for the king's forgiveness of the child then the concubine was punished with severe punishment. The King, the Empress and their son re united once again.

\section{Conclusion}

Related tales as a character learning tool for children are concluded as follows : Fairy tales contain great moral values (adi luhung). 2. Folk tales are still relevant for today as a character learning tool. The teaching values contained in this folk tale are sincerity, honesty, accepting, harmonious, and patience. In this globalization era, folk tale revitalization needs to be done, both through formal and non-formal education. To maintain noble values in folk tales, parents and teachers play an important role to intensely tell stories to children. Tales can be included in local content in the basic intermediate education curriculum.

\section{References}

[1] J. Dananjaja, Folklor Indonesia. Jakarta: Pustaka Utama Grafiti, 1997.

[2] A. Semi, Anatomi Sastra. Padang: Angkasa Raya, 2003.

[3] J. H. Waluyo, Prosa Fiksi dan Puisi Drama Bagian II. Surakarta: Pascasarjana UNS, 2006.

[4] Suyitno, Sastra, Tata Nilai, dan Sastra Baru Indonesia. Yogyakarta: Hanindita, 1986.

[5] S. Marwanti, Pendidikan Karakter. Yogyakarta: Familia, 2011.

[6] Furqon Hidayatullah M, Pendidikan Karakter Membangun Bangsa. Surakarta: Yuma Pustaka, 2010.

[7] H. Kridalaksana, Kamus Linguistik (edisi ke-3). Jakarta: PT. Gramedia Pustaka Utama, 2011.

[8] E. Subroto, Pengantar Metode Penelitian Linguistik Struktural. Surakarta: Universitas Sebelas Maret, 1992.

[9] H. Sutopo, MetodePenelitianKualitatif. Surakarta: UniversitasSebelasMaret Pres, 1988.

[10] N. K. Ratna, Sastra dan Cultural Studies Representasi Fiksi dan Fakta. Yogyakarta: Pustaka Pelajar, 2007.

[11] U. T. Amalia and E. Purwaningsih, "Local Wisdom Tourism Development of Semarang With Tourism Cluster System As an Action for Sustainble Economics Development," Proc. Educ. Lang. Int. Conf., vol. I, no. 1, pp. 871-879, 2016.

[12] M. I. Ahnaf and D. N. Lussier, "Religious Leaders and Elections in the Polarizing Context of Indonesia," Humaniora, vol. 31, no. 3, pp. 227-237, 2019.

[13] S.T. Widodo and K. Saddhono. "Petangan Tradition In Javanese Personal Naming Practice: An Ethnoliguistic Study." GEMA Online ${ }^{\circledR}$ J. of Lang. Stu. vol. 12 no. 4 pp 1165-1177, 2012 